\title{
The Place of the Law School Library in Library Administration
}

BY MILES O. PRICE

$\mathbf{T}$ THE ADMINISTRATION of the law school library-whether as an autonomous unit under the dean or integrated as a unit of the university library system under the director of libraries-has long been a sore point with both deans and directors. ${ }^{1}$ The matter was brought to a head on March 10,1958, by a letter from John G. Hervey, Advisor to the Section of Legal Education and Admissions to the Bar, of the American Bar Association, addressed to the deans of all "approved" schools, in which he set forth the rule, adopted by the council of the association, that "... it [the law school library] should be administered by the law school as an autonomous unit, free of outside control. Exceptions are permissible only where there is preponderance of affirmative evidence in a particular school, satisfactory to the Council, that the advantages of autonomy can be

1 Since, with one exception, the statements of law librarians on the subject of this paper have been the product of those from autonomous libraries and without general library or integrated law library experience, perhaps I should state whatever qualifications I may perhaps I should state whatever qualifications I may possess for intruding my views on a controversial sub-
ject. Prior to becoming librarian of the Columbia Law ject. Prior to becoming librarian of the Columbia Law had been in library work in other fields for nineteen years, in two large universities and (for seven years) as librarian of one of the largest technical libraries, with a staff then of thirty-eight. My university library work included such diverse positions as that of circulation assistant in a divinity school library, supervision of a 50,000-volume modern languages library, genera reference work, and heading gifts and exchanges. As law librarian and teacher of a course in law librarianship, I for many years was active in personnel placement work in the field, during which time I had extended and constant contact with the deans and directors of many schools employing law librarians, and with whom, by correspondence and personal interviews, I discussed at length their library problems.
Mr. Price is Law Librarian and Emeritus Professor of Law, Columbia University.

preserved and economy in administration attained through centralizing the responsibility for acquisition, circulating, cataloging, ordering, processing, or payment for books ordered...." This Council action was reaffirmed at the 1959 annual meeting of the American Bar Association.

It is my earnest belief that, with respect to the place of the law school library in the administrative scheme, whether autonomous under the dean or integrated under the director, personalities are much more important than formal organization. With all concerned - law school and central library-working for the benefit of Dear Old Siwash, any setup will work admirably, within budget limitations. On the other hand, a group of prima donnas bent more on maintaining their personal prerogatives than on achieving their function of service to their university will wreck any scheme. Granting this, there are still measurable theoretical advantages and disadvantages under either arrangement.

It should be borne in mind to begin with that very few law school libraries are either entirely integrated or autonomous. Most "autonomous" libraries are subject to one or more of the following: 
book and binding fund allocations by the central library, technical processing controls, university-wide salary regulations, division of librarians' duties between library administration (paid for by the director) and teaching (paid for by the dean). The principal stigmata of the so-called "autonomous" law school library are closer budget control by the law school, hiring and discharge of library personnel, and book selection autonomy. It is in the discussions of the exercise of these functions, as between director and dean, that the most significant analytical fallacies occur.

To advert to personalities: The dean is the most important single factor in developing the collection and rendering reasonably satisfactory service-and this whether the library is autonomous (as most law school libraries are to some extent) or integrated (as some of the largest and best are). With a library-minded dean, conscious of the place of the law library in his scheme of things and willing to fight for it, success within budget limitations is almost assured under either system. On the other hand, if the dean is indifferent to the library needs, or weak, your autonomous library is a mess (and for every unsatisfactory law library in a centralized system I can show you an autonomous library just as bad). Contrariwise, in a centralized system the law library may or may not be a step-child, depending upon how enlightened the director is, and how willing to cooperate in solving the peculiar problems of the law library.

The next important factor in a successful law school library is the law librarian. The dean's interest in his library is only one of his many interests; the director's is spread throughout the whole campus system; but the law library is its librarian's career. Properly chosen by reason of education, experience, and personality, he can, if given his head to a reasonable extent, develop his collection and render good service to his clien- tele, regardless of the formal organization.

The principal argument advanced in favor of law school control of the library is that the library serving the law school occupies a unique position among professional libraries and so should not be governed by general administrative rules. It is the laboratory of the law school, the repository of source as well as of secondary material. Its material is not only highly specialized (a quality it shares with the libraries of other disciplines, such as medicine and engineering), but the books are of a most complicated character, requiring for their effective selection and service training in their subject matter and makeup. Library training and experience in general libraries alone are not sufficient. Since the law faculty is so much more familiar with the problems involved than the central library administration, it should control the library; the control should be close, not remote from an ivory tower.

The only point in the above which is not common to all professional school libraries is the uniqueness of the law library as a laboratory, with such highly specialized types of books as to require special knowledge and techniques for their effective utilization in serving the clientele. As a librarian with nineteen years' experience in general university and technical and scientific libraries before coming into law, I can vouch for the validity of this point; until directors come to understand this and act accordingly, there will be lack of rapport between the law school and the general library.

Another point stressed by the law school is that the faculty, all law-trained and requiring for the key library positions law-trained personnel, believes that it, not the central library, is uniquely equipped by understanding of the subject matter and curriculum to select the library books and to appraise the qualification of the librarian and professional staff. It concedes the value of profes- 
sional library training-which it more and more requires of its staff-but asserts the paramount necessity of law training in addition; and, since librarians trained in both disciplines are now available, it sees little reason for the intermediation of the central library.

As a law librarian who learned his law and law books on the job, I believe wholeheartedly in the need of the lawtrained librarian. In addition, however, he needs broad library training and experience, a fact which law schools concede, as is shown by the fact that, particularly since World War II, practically all the better jobs have gone to holders of both law and library school degrees. A fallacy in the reasoning of the law schools, however, is that the director does not realize the professional needs of the law school library. In fact, as will be pointed out later, it is common practice for the head and assistant librarians of law schools to be chosen only after consultation with the law school.

Most of the other advantages claimed for the autonomous law school library fail to withstand factual analysis-always granted that prima donnas and empire builders do not interfere with library operation.

\section{Budget Control}

It is commonly asserted that in the integrated library the dean has nothing to say about library funds. That is up to the dean, and is not inherent in the organizational setup. Budgets are not made, and certainly not adopted, in a vacuum in the director's office. In the integrated library the law librarian with any sense has his ear to the ground to learn of the dean's desires. So at budget time he consults the dean as to all his financial needs for the coming year, for books and continuations, for staff and for major equipment.

Furthermore, the dean is a very important member of the university ad- ministrative community. He is usually a member of the council or senate considering budget demands of all university departments, and has his day in court on library as well as law school matters. Paradoxically, the dean is in the position of being able to fight more wholeheartedly for integrated library budget items than if the library were under his complete law school control: It is no skin off his nose if they are granted, whereas if on the law school budget they might make his total too large and result in cuts for other law school items. In two recent instances known to me autonomous libraries actually encountered this situation, and suffered.

As for fund control after the appropriation is made, there is considerable of this, by moral suasion if not directly. For example, the director follows budget lines, or departs from them only in unusual circumstances and by permission. Law library items in the central budget commonly have their own lines and are not merely a part of a lump sum, juggled more or less at will between departments by the director. Neither is the law library budget necessarily a fixed percentage of that of the entire library system, as is true of book funds for some outstanding autonomous law school libraries.

\section{ACquisitions And Technical Processes}

Book Selection. Frustration in this in the integrated library is a universal argument brought up against integration, also without much basis in fact. It all depends upon the cooperation between director and dean. A vigorous dean, through his library committee, makes his policies and immediate wants known; a wise director goes along, with a liberal exercise of his discretionary powers. I know book selection policies among law school libraries very well, and I am quite certain that where the law library is on 
the general library campus the non-duplication policy general among libraries is observed by autonomous libraries to just about the same extent as by the integrated ones; to do otherwise would be indefensible. It is elementary that money spent for duplicating book $\mathrm{A}$ which is in Business cannot purchase a new book $B$, which is not in Law but needed there; and that if the needs of Law can be served by borrowing book A from Business, Law may then buy book B. Within broad guidelines, established in consultation between general library and law school, the law librarian's discretion should seldom be interfered with; it is by no means inherent in the integrated scheme that it should be.

Gifts and Exchanges. These are important. In the integrated setup, those received by the central library are sent to Law if of appropriate subject matter. In the absence of difficult personnel, this policy can just as well be followed for the autonomous library.

Cataloging. This is a most important aspect of law library service, but no problem of organization should be involved: In many autonomous libraries the cataloging is farmed out to the general library. It is important, however, that the work be done in Law (for expedition and opportunity of consultation with law-trained personnel), and that Law, within the confines of decent cataloging policies, be permitted to set the policies.

Book Classification. It is charged that sometimes the general library forces the integrated library to classify its books according to some general classification scheme. If this has been done anywhere, it is very silly indeed. There is at present no satisfactory classification scheme for Anglo-American law books, though the Library of 'Congress is about to embark seriously upon the study of its Schedule K for law.

Binding. In my own experience, tl allocation by the general library in int. - grated schemes works better than that in autonomous: At least binding money is spent for binding and not diverted to some other law school purpose. It is not, however, inherent in either scheme and is not an argument for either setup.

Order Routine. Delay and misunderstanding caused by channeling orders and books received through the central library acquisitions department are common and often justified. There is inherent some delay, and law librarians feel that they lose many antiquarian books through delay, lack of knowledge of sources, and the like. If shipments are made in gross from abroad to the cen. tral library, Law frequently does not receive its continuations as promptly as in an autonomous setup. On the other hand, the expertise of the central library saves the law library many a headache in routine matters. The difficulty is that in both cataloging and order work processing outside of Law causes delay.

A point not always considered by the critics of the integrated library is that of staff quarters: The law school building and its library quarters must be substantially enlarged if the technical processes are to be done in Law. Furthermore, at least at Columbia, many supplies are provided by the central library free to Law, which, in the autonomous setup, would have to be provided by the law school.

\section{STAFF}

Frequent objection is voiced to any degree of staff control by the director, whether appointment, payment, or supervision, and there is often validity, particularly when the director equates all central library salaries to those of supposedly similar law jobs.

The degree of control varies widely. In some universities the law school has complete control; in others, the director. A not uncommon arrangement is the splitting of the head librarian's salary 
payment between the dean and the director, with the dean paying the librarian a stipend for whatever teaching he does, and the director for his services as librarian. This device also helps solve the problem of faculty rank and status, which are important to the librarian.

In the fully autonomous library, appointment and salary are Law matters, but even here, in all schools with which I am acquainted, the central library salary scale is substantially followed for most jobs, certainly for clericals and professionals other than librarian, first assistant librarian, and perhaps the reference librarian. In the autonomous library the three positions mentioned, calling for professional subject-matter competence, properly tend to be compensated as law jobs. As for the rest, there is no good reason why a routine professional or clerical job performed in a law library should be treated differently than in any other learned library, and, as far as I know, the campus-wide library scale is carefully adhered to, even in autonomous schools.

Real trouble comes for the integrated library when, as too often happens, the director equates the law positions with all others in his system. The really pernicious practice is to limit the law librarian's salary to the amount of the assistant director's. This is an indefensible practice which has resulted in the actual and potential loss of many a good head law librarian in integrated schools.

A major point in the A.B.A. directive is that appointments should be made by the dean, and that those carrying faculty rank should be approved by the faculty. This is flogging a dead horse. Integrated library appointments of librarian or assistant librarian (particularly when the latter also is limited to those with law degrees) are "by and with the consent" of the law faculty. It would be a most unusual case in which the director would arbitrarily appoint either without the full knowledge and consent of the
Iaw faculty, which body normally would have met and carefully considered candidates for the position. Lesser positions can just as well be filled from the larger reservoir of central library personnel files.

The size of the staff causes some diffculty between the integrated library and the dean. The dean may feel that additional personnel are needed, but has only persuasive powers to enforce his will and dislikes interfering in another officer's jurisdiction. By the same token, it is my own experience that the small integrated library has a better staff than a similar autonomous library. Librarianship is the central libraries' business, and they are equipped and anxious to give and appreciate expert operation. The same is too often not true of the autonomous library.

Staff control by the director may result in continual frustration if the director is a prima donna or empire builder, jealous of his prerogatives and unwilling to delegate sufficient of them to the law librarian.

\section{Advantages of the Integrated Law LIBRARY}

Such advantages as there are inhere chiefly in the library really too small to stand on its own feet as an efficient, separate administrative unit. Running a library is library business, a matter for experts in this profession. Any university having a law school has a fairly large and well organized library system, staffed by experts who make library administration a career and are especially trained for it. Librarianship is not static, and its developments must be followed, as is true of any learned profession. Librarians, through their associations, do this; the dean lacks time or interest for it.

In a small autonomous law library the tubrarian tends to be a lawyer plucked from a graduating class, with little or no 
training or interest in the science of librarianship, though this is by no means always true. On the other hand, increasingly, the law school librarian of medium and large sized libraries is both a law and library school graduate, with a staff and collection comparable with those of many college libraries. Such a librarian should be able to stand on his own feet, fully professional as to both the law and the library sides of his job. I believe there may be definite advantages in autonomy for the large, selfcontained library, though by no means to the extent claimed for it.

University-wide, the integration of all units of the library system under the director is said to make for added efficiency and economy. This the dean is likely to deny.

An objection earnestly made to autonomy is the consequent difficulty of intralibrary loans, between Law and any other central library department. It is asserted seriously that, following such autonomy, the central library would refuse or be reluctant to lend its books to Law, and that as a consequence Law would have to purchase material it would otherwise borrow. I can not conceive of any university president who would permit such an absurdity.

\section{Head Law Librarians' Attitude}

One factor of great importance remains to be mentioned, the head librarians' attitude. Massey ${ }^{2}$ has recorded the almost unanimous preference of law school librarians answering her questionnaire for the autonomous library. This accords with the knowledge of other school librarians and with my own long and extensive experience in placement work. This preference is very important to the school seeking a qualified law librarian. There is now a bull market in

${ }^{3}$ M. Minnette Massey, "Law Scliool Administration and the Law Librarian," Journal of Lcgal Education, $\mathrm{X}(1957) 215-21$. qualified law librarians, and to a great extent such a person can pick and choose among law school jobs. Therefore, the library seeking an outstanding person must have something to offer.

Salary. This is probably the first attraction. The minimum now paid in large or fairly large law school libraries is about $\$ 12,000$, with ranges up to above $\$ 16,000$. Head librarians' salaries in autonomous libraries definitely average higher than in integrated ones because deans tend to think in terms of law faculty status and salaries generally, directors in terms of the usually lower library ranges. Librarians have the feeling, also, that they benefit more by across-the-board faculty salary increases, but this is by no means always true. In any event, the law librarian's heart follows his pocket book, other things being equal.

Academic Status and Rank. These are dear to the law librarian's heart and are perhaps of even greater importance than salary alone (partly because salary and status are so often tied together). The librarian accorded academic rank and status in his institution is thereby made a member of the lodge in good standing, which is significant in his relations with both faculty and students. To be sure, in most schools professional library staff members have a sort of academic status, varying greatly with the institution, but it is an ersatz arrangement, generally regarded as inferior to that of a seat on the faculty served. The difference is both a matter of prestige among his faculty and students and of direct communication between faculty and librarian. Given anything like equal opportunity as between jobs, the law school librarian will almost invariably accept the autonomous library position. All this has one important by-product, tending to raise the quality of head law school librarians: The schools say, with perfect logic, "If you're to be made a member of our 
faculty, you've jolly well got to measure up to the same selection standards as the rest of us." This separates the men from the boys. It may be noted that integrated librarians also have been accorded full professorial rank and status by the law schools served, and that autonomous libraries have rejected it; here again it is a matter of personality rather than of organization.

\section{SUMMARY}

Nearly all the advantages urged in favor of the autonomous law school library and against the integrated one fall before careful analysis: Given a strong and interested dean and a capable and reasonable director, either will work. Either will just as assuredly fail if the dean will not fight for his library and the director is an empire builder. Just as many, proportionately, fail of realizing their potential under one scheme as the other, but the results from the autonomous library are more likely to be unsatisfactory with the small library than with one large enough to be selfsufficient under the leadership of a well trained and otherwise competent librarian.

Budget control, book selection, and processing need cause little difficulty under either system. The quality of service to users need not be dependent at all upon formal organization. We have a saying at Columbia that every time the dean sneezes the library says "God bless you." The dean of any school can always get the sort of service he wants from the integrated library, within budgetary limitations, and is likely to be relieved thereby from many arduous routine detail and space troubles.

The principal dangers and disadvantages of the autonomous library are the too frequent lack of interest or aggressiveness on the part of the dean, resulting in a poor technical staff and administration, as opposed to the expertise of the central library and its constant contact with agencies aiming to improve library methods, and its insistence upon high technical standards.

The disadvantages said to be inherent in the integrated library (though in practice they are less than in theory, except as to faculty rank and status) have chiefly to do with control: An empirebuilding director, unwilling to delegate sufficient power of operation to his law librarian, tying his salary to that of his assistant director, and paying too little deference to the desires and needs of the dean can play hob with library development and service if the dean lets him. It has been done. The law librarians, with practical unanimity, prefer the autonomous library; the large integrated library, at least unless it can persuade the law school to grant full professorial rank and status to its librarian, stands in danger of securing only second-rate head librarians. A fairly common solution of this dilemma is the joint appointment of the law librarian (especially of an integrated library) by both dean and director, in which case the major share of his combined salary is paid by the director. Academic rank and status are thus granted, and the librarian is satisfied on this point.

To repeat my first observation: Personalities are more important than formal organization; it's like marriage, which succeeds or fails on the basis of the parties participating. There is much to be said for either the autonomous or the integrated library, but both the dean and the director should realize that cooperation is vital.

Mr. Hervey's dream of a law school library without "outside control" is, of course, just that: Any agency of a university is subject to control. There is no Santa Claus, and placing the law library under the dean is not going, automatically, to solve all problems in which money is involved, which is about all of them. 